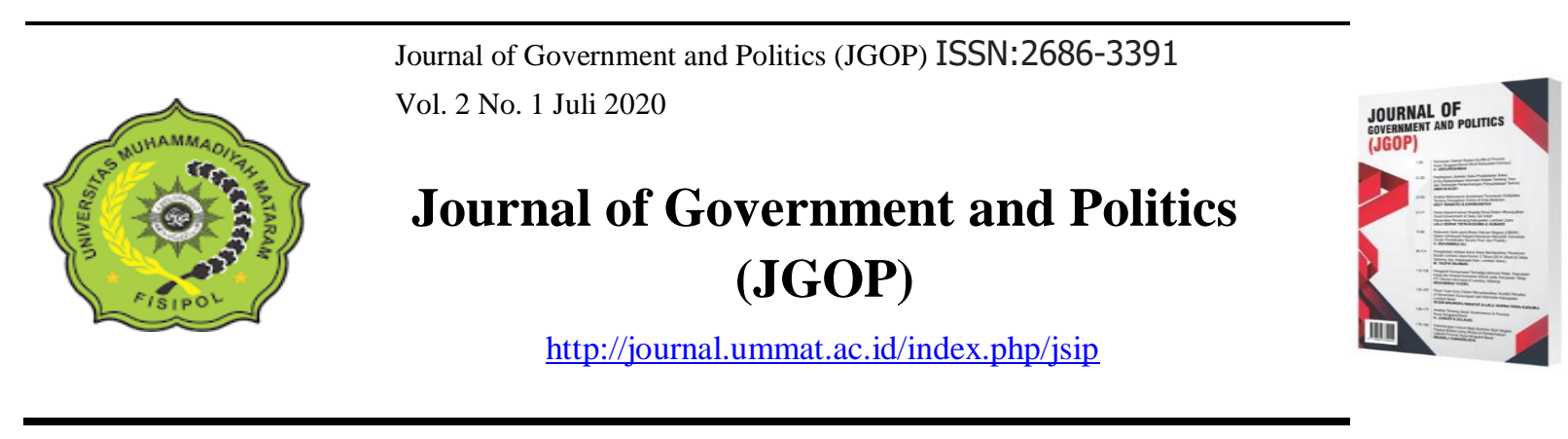

\title{
KEGAGALAN TUAN GURU H.LALU FARHAN RASIYD MAKBUL DALAM MEMENANGKAN PEMILIHAN UMUM LEGISLATIF TAHUN 2014
}

\author{
Muhammad Rudi Hadi ${ }^{1}$, Ayatullah Hadi $^{2}$, Lalu Sopan Tirta K ${ }^{3}$ \\ 1,2,3 Universitas Muhammadiyah Mataram
}

\begin{tabular}{l}
\hline InfoArtikel \\
\hline Sejarah Artikel: \\
Diterima: 06-05-2020 \\
Disetujui: 18-07-2020 \\
Dipublikasikan :21-07- \\
2020
\end{tabular}

Kata Kunci :

Tuan Guru, Party ID, PAN

\section{Abstrak}

Tuan Guru sebutan masyarakat Lombok atau Gelar yang diberikan oleh masyarakat terhadap Individu yang dihormati, karena dilihat dari tingkat pendidikan dan pemahaman tentang agama. Masyarakat Lombok Nusa Tenggara Barat mayoritas penduduk yang beragama islam, melahirkan banyaknya Tuan Guru. Di masyarakat Lombok, tatanan-tatanan masyarakat amat sangat tergantung kepada apa dan bagaimana ajaran tuan guru yang dijadikan sebagai panutan. manakala tuan guru mereka lebih mengkedepankan doktrin dan prinsip-prinsip yang diterima oleh akal dan naluri mereka, atau apabila doktrinannya lebih mengkedepankan ajaran-ajaran tasawuf, maka secara otomatis dalam apikasinya kehidupannya lebih tercermin corak-corak sufisme, yangt tentunya sesuai dengan ajaran tasawuf (tarekat) yang diterima dari tuan guru nya.

Dalam penelitian ini penulis akan menggunakan pendekatan kualitatif dengan metode analisis deskriftif. Pembangunan sosial budaya sebagaimana adanya saat ini merupakan salah satu tantangan terbesar bagi setiap pemerintah baik itu pemerintah pusat maupun pemerintah daerah dalam hal ini yaitu pemerintah desa Ganti mempunyai tantangan untuk tetap membentengi sosial budaya dari terjangan arus modernisasi kota, dan mengembangkan budayabudaya yang selama ini di anggap positif sesuai dengan apa yang menjadi ciri masyarakat desa Ganti secara khususnya sebab kalau identitas lokal di hilangkan termasuk juga budaya lokal masyarakat Desa Ganti maka identitas lokal atau ciri khas masyarakat Desa Ganti tidak akan ada melebur dengan budaya modernism maka apa yang sudah di bangun oleh nenek moyang sebelumnya kalau tidak di jaga maka akan pudar dan bahkan punah seiring dengan pergantian regenerasi. Menurut penulis setelah mengadakan penelitian di Desa Ganti dalam mengidetifikasi partai (Party ID) Amanat Nasional. penulis dapat menilai bahwa Partai Amanat Nasioanal (PAN) tidak sukses dalam melaksanakan proses sosialisasi politik terhadap masyarakat pemilih di wilayah Desa Ganti Kabupaten Lombok Tengah pada pemilihan legislatif tahun 2014. 


\section{FAILURE OF MASTER TEACHER H.LALU FARHAN RASIYD MAKBUL IN WINNING THE LEGISLATIVE GENERAL ELECTION IN 2014}

\section{Abstract}

Tuan Guru refers to the Lombok community or the title given by the community to individual people, because it is seen from the level of education and understanding of religion. The Lombok community in West Nusa Tenggara has a majority Muslim population, giving birth to many Tuan Guru. In the Lombok community, community orders are very much dependent on what and how the teachings of the teacher are used as role models. when their master teachers put forward the doctrines and principles accepted by their reason and instinct, or if the doctrine prioritizes the teachings of Sufism, then automatically in the apikinya life is more reflected in the characteristics of Sufism, which is certainly in accordance with the teachings of Sufism (tarekat) ) received from the master teacher.

In this study the authors will use a qualitative approach with descriptive analysis methods. Socio-cultural development as it is today is one of the biggest challenges for every government, both the central government and regional governments, in this case, the village government of replacing it has the challenge to continue to fortify the social culture from the lunge of the city modernization currents, and develop cultures that have been is considered positive in accordance with what characterizes the people of the village in particular in particular because if the local identity is removed including the local culture of the people of the village, the local identity or the characteristics of the people of the village will not be merged with modernism then what has been built by If our ancestors were not preserved, they would fade and even become extinct along with regeneration changes. According to the author after conducting research in the Village Change in identifying parati (Party ID) National Mandate. the author can judge that the National Mandate Party (PAN) was not successful in carrying out the process of political socialization to the voting community in the Changing Village area of Central Lombok Regency in the 2014 legislative elections.

\footnotetext{
*Alamat Korespondensi:

${ }^{1}$ MuhammadRudi@gmail.com

2 hadi.ayatullah@yahoo.co.id

3 Sasakku25@yahoo.co.id
} 


\section{PENDAHULUAN}

Transisi menuju demokrasi cenderung melibatkan kesimpangsiuran norma. Dalam kesimpangsiuran itu, ada keperluan untuk melerai konflik-konflik nilai yang terjadi.Untuk keluar dari situasi pelik ini, maka kesepakatan yang relatif mudah diraih adalah dengan mengacu pada aturan-aturan resmi.Sejalan dengan hal itu, para pihak yang terlibat dalam kontestasi juga bersembunyi dibalik norma-norma legal.

Legalisme menjadi sandaran bertindak manakala demokratisasi yang berlangsung terjebak dalam kontestasi norma. Masyarakat awam yang telah kehilangan tokoh panutan tidak lagi bisa mengandalkan proteksi moral para tokoh panutan itu sendiri yang bermaksud untuk mencari kemenangan dalam kontestasi yang berlangsung. Faktanya, pengurus partai politik yang merupakan bagian dari elit, pada kasus kontestasi Pilkada Langsung lebih menunjukkan ciri-ciri seperti broker yang terlibat dalam politik kontraktual dengan aktor kandidat Elit ekonomi yang eksis di ranah lokal, cenderung hanya mengekor penguasa untuk mendapatkan keuntungan finansial. Sementara elit tradisional terutama Tuan Guru, posisi perannya kadangkala tidak jelas, apakah ingin menampilkan diri sebagai "kiai politik", atau benar-benar sebagai figur panutan masyarakat yang steril dari politik. Dalam realitasnya Tuan Guru pada umumnya tidak mampu menunjukkan integritas personalnya untuk menunjukkan kompatibilitas ilmu agamanya sebagai solusi masalah dari anomali praksis demokrasi politik yang bermuara pada aspek-aspek patologis.

Indonesia sendiri mempunya enam agama yang diakui oleh pemerintah, sehingga jika dipisah berdasarkan agama, indonesia mempunyai enam tokoh spritual. Akan tetapi dengan mayoritas penduduknya yang beregama islam, terutama daerah pemilih mayoritas islam, sehingga mendekati para Ulama merupakan cara yang cukup ampuh untuk merangkul pemilih. Tidak ditemukan informasi, sejak kapan Tuan Guru bersentuh dengan dunia politik, dan menjadi bagian dari political society. tetapi jikalau membaca sejarah perkembangan ualama di Indonesia membangun kekuatan politik melalui organisasi masa, misalnya Nahdlatul Ulama ("Kebangkitan Ulama"), maka tuan guru sebagai eksponen ulama dapat diduga mulai berkiprah dalam dunia politik sejak Nahdlatul Ulama didirikan tahun 1926.

Ulama adalah salah satu entitas yang memiliki pengaruh besar dalam arus sosial politik di indonesia. Kyai di Jawa Timur dan Madura; Buya di Sumatera Barat; dan Tuan Guru di Nusa Tenggara Barat, gelar yang diberikan masyarakat terhadap tokoh agama, sebagai patron modal pengetahuan agamanya. Di Lombok Nusa Tenggara Barat, Tuan Guru sebutan masyarakat Lombok atau Gelar yang diberikan oleh masyarakat terhadap Individu orang, karena dilihat 
dari tingkat pendidikan dan pemahaman tentang agama. Masyarakat Lombok Nusa Tenggara Barat mayoritas penduduk yang beragama islam, melahirkan banyaknya Tuan Guru.

Di masyarakat Lombok, tatanan-tatanan masyarakat amat sangat tergantung kepada apa dan bagaimana ajaran tuan guru yang dijadikan sebagai panutan. manakala tuan guru mereka lebih mengkedepamkan doktrin dan prinsip-prinsip yang diterima oleh akal dan naluri mereka, atau apabila doktrinannya lebih mengkedepankan ajaran-ajaran tasawuf, maka secara otomatis dalam apikasinya kehidupannya lebih tercermin corak-corak sufisme, yangt tentunya sesuai dengan ajaran tasawuf (tarekat) yang diterima dari tuan guru nya.

Dilihat dari perspektif kepentingan, Tuan Guru barangkali tidak bisa diabaikan. Berdasarkankondisi di lapangan, peran Tuan Guru itu paling tidak diasumsikan penting dalam duaperkara. Pertama, sebagai perantara jagat spiritualitas.Kedua, sebagai penguasa pondok pesantren. sehingga para tuan guru melibatkan diri dalam politik praktis karena dilihat dari kemaampuan untuk memobilisasi masa pemilih. barangkali ini yang kemudian menjadi harapan bagi Tuan Guru untuk memenangkan kiontestasi pemilihan legislatif secara langsung.

Bagi masyarakat islam di pedesaan, seorang Tuan Guru memegang peranan ini untuk membentengi umat dari cita-cita islam terhadap ancaman kekuatan-kekuatan sekuler dari luar. Tuan Guru merupakan pemimpin karismatik dalam bidang agama. oleh karena sifatnya yang karismatik, maka posisi Tuan Guru dalam masyarakat, hanyalah sifat sementara dan cepat berakhir. karena otoritasnya tidak didukung oleh kesinambungan kelembagaan, maka ketidak berhasilan dalam menanamkan islam kepada para pengikutnya.

Keyakinin semacam ini menimbulkan adanya keterikatan moral dari masyarakat terhadap Tuan Guru sehingga memungkinkan para Tuan Guru tersebut untuk menanamkan pengaruhnya dalam masyarakat termasuk dalam pilhan-pilihan yang bersifat politis, misalnya dalam memilih partai politik. dengan demikian peran Tuan Guru dalam menentukan sikap politisnya masyarakat secara luas bias dikatakan dominin. karena secara tidak langsung masyarakat telah menempatkan Tuan Guru sebagai sumber nilai dalam menentukan sikap politis yang ditawarkan kepada mereka. dengan kata lain, sikap politis Tuan Guru atau keterlibatanya dalam politik praktis akan dinilai oleh masyarakat sebagai pilihan terbaik untuk diikuti. (Darmansyah, 2003)

Pemilihan umum tahun 2014 di NTB dalam pemilihan Dewan Perwakilan Daerah (DPRD) Provinsi terdapat 9 orang Tuan Guru yang mencalonkan diri, mereka harus tertatihtatih untuk mendapatkan suara dan simpati rakyat, hasilnya hanyalah 4 orang Tuan Guru yang lolos ke Udayana. Di tingkat Desa dalam pemilihan Dewan Perwakilan Daerah (DPD) Kabupaten Lombok Barat, tepatnya di desa Eyat Mayang, Kecamatan Lembar Kabupaten 
Lombok Barat dari 41 peserta terdapat 4 orang Tuan Guru yakni; TGH. L. Nurul wathoni S.Pd,I, TGH. L. Mara Sira'I S,Ag, Drs. TGH. Muchlis Ibrahim, M,Si, TGH. Muharrar Mahfuz. Telah terjadi pragmentasi pemilih terhadap Tuan Guru tersebut, TGH. L. Nurul wathoni S.Pd,I, berulangkali mendapat suara kosong di tempat pemungutan suara (TPS): TPS $1=2$ suara, TPS $2=6$ suara, TPS $3=3$ suara,TPS $4=0$ suara, TPS $5=3$ suara, TPS $6=3$ suara. TPS 7 dan $8=0$ suara.(Dedi Putrawan. 2015)

Penelitian dengan judul "Dekarismatisasi Di Lombok NTB (Studi Tentang Pudarnya Pesona Tuan Guru Dalam Politik PemilihanUmum 2014)”. Oleh Agus Dedi Putrawan tahun 2015. Hasil dari penelitian memperlihatkan bahwa Kharisma yang melekat pada diri Tuan Guru khususnya di tengah-tengah masyarakat suku Sasak membuat penelitian ini menarik, karena dalam pembahasannya telah melahirkan paradog anatara penghormatan, rasa cinta terhadap pesona Tuan Guru di satu sisi, merasa kurang hajar (su'ul adab) di sisi lain. Perasaan delematis itu akhirnya melahirkaan suatu pandangan bahwa Tuan Guru adalah public figure yang tak lepas dari perhatian orang banyak, perannya dalam semua bidang kehdupan memposisikan dirinya sebagai tokoh sentral di tengah-tengah masyarakat suku Sasak. Kharisma Tuan Guru akan memudar ketika keluar ia keluar melewati wilayah tutorialnya sendiri atau basis legitimasi (akuan karisma). Ada wilayah dimana kekuatan kharisma atau legitimasi dari pengikutnya begitu kuat.

Demokrasi adalah bentuk atau mekanisme system pemerintahan suatu Negara sebagai upaya mewjudkan kedaulatan rakyat (kekuasaan warganegara) atas Negara untuk dijalankan oleh pemerintah Negara tersebut. (Redaksi Great Publisher, 2009)

Dalam demokrasi lokal dan pemilu langsung suatu pemerintahan Negara tidaklah dapat dikatakan menganut system demokrasi, apabila pemerintahan negara tersebut tidak pernah menyelenggarakan pemilu. Dalam pemerintahan yang demokratis maka kekuasaan tertinggi adalah berada ditingkat rakyat. Oleh karena itu kekuasaan untuk mengatur negara sepenuhnya ditentukan oleh rakyat, sedangkan mekanisme dalam pergantian kekuasaan penyelenggaraan negara tersebut diatur melalui pemilu. Dengan demikian pemilu adalah merupakan sarana yang paling strategis untuk mengwujudkan dan mengembangkan demokrasi dalam bernegara yang berkedaulatan rakyat.

Menurut Hasan Basri Marwah, istilah Tuan Guru bisa ditelusuri sampai abad ke-18 ketika tiga orang alim ini menggunakannya pertama kali. Pertama Tuan Guru Umar Kelayu, Tuan Guru Abdul Hamid presak Pagutan dan Tuan Guru Sekar bela. Konon mereka bertiga sangat harmonis dan tinggi tingkat toleransinya dalam perbedaan pandangan.Mereka bertiga 
cukup lama tinggal di Hijaz untuk menunaikan ibadah haji dan menimba ilmu, (SamsulAnwar, 2012).

Tuan Guru bagi masyarakat Lombok adalah orang yang menguasai dan mengajarkan ilmu dan tata nilai agama. Merujuk pada kata "Tuan" dan "Guru” adalah sebutan kelas sosial yang berada pada kelas tertinggi dalam struktur masyarakat Lombok. Ini menyiratkan pelapisan sosial yang bertumpuk dalam mitra stigmatic yang diciptakan oleh sistem sosial.

Peran Tuan Guru di era kontemporer saat ini semakin sentral, masyarakat bisa menimba atau belajar ilmu agama, mengikuti pengajian, mengadu persoalan kemasyarakatan, memecahkan permasalahan sosial dan sebagainya. Tuan Guru menjadi sosok multifungsi dalam masyarakat dengan karisma yang melekat pada dirinya sehingga selain mengetuai pondok pesantren yang para santrinya berasal dari pelosok-pelosok desa dan kota. Banyak muridnya menjadi Tuan Guru-Tuan dikampungnya. Para Tuan Guru banyak memiliki pengikut yang militan karena sering melakukan pengajian-pengajian dikampung-kampung, kadangkadang sekali satu bulan, satu kali seminggu, bahkan setiap hari. Masayarakat memiliki cara pandang khusus dalam memperlakukan dan berhadapan dengan sosok Tuan Guru: penghormatan, cara sikap, mengundang Tuan Guru dalam acara-acara hujatan. (Agus, 2014)

\section{METODE PENELITIAN}

Kualitatif yaitu metode penelitian yang digunakan adalah penekanan pada observasi wawancara untuk orang, sebagai lawannya adalah gambaran kondisi objektif secara ilmiah, dimana peneliti adalah instrument kunci, teknik pengumpulan data dilakukan secara triangulasi (gabungan), analisis data bersifat induktif dan hasil penelitian kualitatif lebih menekankan makna dari pada generalisasi. Penempatan lokasi penelitian bagi penelitian ilmiah memang berbagai pertimbangan ilmiah maupun pertimbangan pertimbangan praktisnya. Pertimbangan ilmiahnya, apakah lokasinya tersebut terdapat masalah yang banyak dikaji secara ilmiah, bahwa objek tersebut adalah mudah dijangkau, efektif, dan efisien dari segi waktu dan biaya.

Adapun lokasi dalam penelitian ini pada tim pemenangan kampanye (TPK) di Desa Ganti Kecamatan Praya Timur Kabupaten Lombok Tengah. Penulis memilh lokasi penelitian didasarkan pada pertimbangan bahwa lokasi tersebut merupakan lokasi yang sangat tepat untuk memperoleh data atau informasi yang akurat dan relevan dengan permasalahan penelitaian yang ada. Dengan rincian sumber data primer sebagai berikut: 
Tabel 1

Sumber Data Primer

\begin{tabular}{|c|c|c|c|c|}
\hline NO & NARASUMBER & JENIS DATA & METODE & JUMLAH \\
\hline 1 & $\begin{array}{c}\text { Tuan Guru H. } \\
\text { Lalu Farhan } \\
\text { Rasyid Makbul }\end{array}$ & $\begin{array}{c}\text { Keuntungan dan } \\
\text { kerugian mencalonkan } \\
\text { diri melalui Partai } \\
\text { Amanat Nasional } \\
\text { (PAN) }\end{array}$ & Wawancara & 1 \\
\hline 2 & $\begin{array}{c}\text { Tim Pemenangan } \\
\text { Kampanye }\end{array}$ & $\begin{array}{l}\text { Perbandingan suara } \\
\text { calon yang } \\
\text { bersangkutan dengan } \\
\text { suara partai sebagai } \\
\text { perbandingan }\end{array}$ & Wawancara & 1 \\
\hline 3 & $\begin{array}{c}\text { Anggota Partai } \\
\text { Amanat Nasional } \\
\text { (PAN) }\end{array}$ & $\begin{array}{c}\text { Persamaan ideologi } \\
\text { dengan calon yang } \\
\text { bersangkutan }\end{array}$ & Wawancara & 2 \\
\hline 4 & $\begin{array}{c}\text { Masyarakat Desa } \\
\text { Ganti }\end{array}$ & $\begin{array}{c}\text { Relefansi kedudukan } \\
\text { sosial masyarakat dan } \\
\text { kedudukan partai } \\
\text { amanat nasional } \\
\text { (PAN) }\end{array}$ & Wawancara & 26 \\
\hline
\end{tabular}

Sumber: Data diolah penulis

Tabel 1 diatas memperlihatkan bahwa sumber data yang akan di teliti oleh penulis sebanyak 30 orang, dengan rincian sebagai berikut; Tuan Guru H. Lalu Farhan Rasyid Makbul 1 orang, Tim Pemenangan Kampanye 1 orang,Anggota Pertai Amanat Nasonal 2 orang, dan Masyarakat Desa Ganti 26 orang.

\section{HASIL DAN PEMBAHASAN}

Pembangunan sosial budaya sebagaimana adanya saat ini merupakan salah satu tantangan terbesar bagi setiap pemerintah, baik itu pemerintah pusat maupun pemerintah daerah dalam hal ini yaitu pemerintah desa Ganti mempunyai tantangan untuk tetap membentengi sosial budaya dari terjangan arus modernisasi kota, dan mengembangkan budaya-budaya yang selama ini di anggap positif sesuai dengan apa yang menjadi ciri 
masyarakat desa Ganti secara khususnya sebab kalau identitas lokal di hilangkan termasuk juga budaya lokal masyarakat Desa Ganti maka identitas lokal atau ciri khas masyarakat Desa Ganti tidak akan ada melebur dengan budaya modernism maka apa yang sudah di bangun oleh nenek moyang sebelumnya kalau tidak di jaga maka akan pudar dan bahkan punah seiring dengan pergantian regenerasi.

Fenomena yang terjadi akhir-akhir ini dimana kepercayaan masyarakat terhadap Tuan Guru sehingga berdampak pada melemahnya kharisma Tuan Guru di mata para Umat dalam konteks politik atau ruang politik mulai melemah, Tuan Guru yang exis dalam ruang agama terutama dakwahnya mengalami rintangan dan tantangan ketika Tuan Guru mencoba memasuki ruang yang lebih luas yaitu ruang politik dalam memperluas ruang dakwahnya. Tuan Guru merupakan patokan berpendapat dan bertindak masyarakat, contoh nyata dalam melakukan tindakan, dan bahkan menjadi kiblatnya masyarakat Sasak dalam bertanya dan mengadu berbagai macam persoalan sosial keagamaan tetapi dalam konteks politik yang lebih khusus yaitu seperti yang terjadi di Lombok Tengah Desa Ganti menurai banyak persoalan.

1. Tujuan Partai Amanat Nasiunal (PAN)

Partai Amanat Nasional (PAN) yang bertujuan menjunjung tinggi dan menegakkan kedaulatan rakyat, keadilan, kemajuan material, dan spiritual. Cita-cita partai berakar pada moral agama, kemanusiaan, dan kemajemukan. Selebihnya Partai Amanat Nasional (PAN) menganut prinsip non-sektarian dan non-diskriminatif. Untuk terwujudnya Indonesia baru, Partai Amanat Nasional (PAN) pernah melontarkan gagasan wacana dialog bentuk Negara federasi sebagai jawaban atas ancaman disintegrasi. Titik sentral dialog adalah keadilan dalam mengelola sumber daya sehingga rakyat seluruh Indonesia dapat benar-benar merasakan sebagai warga bangsa. kemudian dimanfaatkan sedemikian rupa oleh partai-partai politik dalam rangka membuka kerjasama politik guna mencapai tujuan politik mereka di daerah.

Berangkat dari hal tersebut, Tuan Guru H. Lalu Farhan Rasiyd Makbul dari Desa Ganti, yang menggunakan Partai Amanat Nasional (PAN) sebagai kendaraan politiknya maju menjadi calon angota DPRD Provinsi NTB Tahun 2014. Sebagaimana hasil wawancara dengan Tuan Guru H. Lalu Farhan Rasiyd Makbul. Sebagai berikut: "Ketika memilih kendaraan politik, ini saya juga harus banyak melakukan pertimbangan yang matang, baik secara kepentingan maupun ideologi ketika sudah memutuskan maju menjadi calon anggota dewan, mengenai hal ini juga tidak terlepas dari bacan-bacan internal mapun ekternal yang ada di genderan yang kita tuju".

Dilihat dari perspektif kepentingan, Tuan Guru barangkali tidak bisa diabaikan. Berdasarkan kondisi di lapangan, peran Tuan Guru itu paling tidak diasumsikan penting dalam 
dua perkara. Pertama, sebagai perantara jagat spiritualitas. Kedua, sebagai penguasa pondok pesantren. sehingga para tuan guru melibatkan diri dalam politik praktis karena dilihat dari kemampuan untuk memobilisasi masa pemilih. Melihat hal ini kemudian dimanfaatkan sedemikian rupa oleh partai-partai politik dalam rangka membuka kerjasama politik guna mencapai tujuan politik mereka di daerah. Seperti halnya dengan Partai Amanat Nasional (PAN) yang membuka kerjasama politik bersama salah satu tokoh agama Tuan Guru H. Lalu Farhan Rasiyd Makbul dari Desa Ganti, yang menggunakan Partai Amanat Nasional (PAN) sebagai kendaraan politiknya maju menjadi calon anggota DPRD Provinsi NTB Tahun 2014. Sebagaimana hasil wawancara dengan Tuan Guru H. Lalu Farhan Rasiyd Makbul.

Setiap caleg yang sudah siap maju sebagai calon anggota dewan, tentu sudah memikirkan dan mempertimbangkan dampak dari keputusannya dalam memilih partai sebagai kendaraan politiknya, seperti halnya juga yang disampaikan oleh Tuan Guru H. Lalu Farhan Rasiyd Makbul, mengenai untung-ruginya ketika sudah memutuskan Partai Amanat Nasional (PAN) menjadi kendaraan politik maju menjadi calon anggota DPRD Provinsi NTB Tahun 2014. Sebagaimana hasil wawancara dengan Tuan Guru H. Lalu Farhan Rasiyd Makbul. "Kenapa dulu pada tahun 2009, H. Lalu Farhan Rasiyd Makbul memilih PKS sebagai kendaraan politiknya, tentu ada pertimbangan ketika H. Lalu Farhan Rasiyd Makbul melihat PKS ini, dan yang kedua ketika pada tahun 2014 H. Lalu Farhan Rasiyd Makbul memilih Partai Amanat Nasional (PAN) sebagai kendaraan politik tentu juga dia melihat internal dari Partai Amanat Nasional (PAN), dalam konteks siapa pesaing dia di internal. Tidak mungkin juga itu tidak didasarkan dari analisi kekuata-kekuatan yang dia punya, ketika H. Lalu Farhan Rasiyd Makbul mau melalui Partai Amanat Nasional (PAN) sebagai kendaraan politiknya".

2. Tuan Guru Dalam Politik Nasional

Keterlibatan Tuan Guru dalan pentas politik, merupakan sebuah keniscayaan yang tidak bisa dihalan-halangi. Partisipasi politik Tuan Guru disetiap lembaga kebijakan publik, termasuk di parlemen adalah bagian dari pilihan kita mengadopsi sistem demokrasi yang merupakan di dalamnya pengakuan hak asasi bagi setiap warga yang sangat mendasar. Karena hak asasi itulah, sesungguhnya begitu banyak alasan, mengapa begitu penting Tuan Guru terlibat dalam kancah politik praktis. Untuk itulah begitu penting (Urgent) nya keterlibatan Tuan Guru sebagai pelaku yang berada langsung pada posisi pembuat kebijakan, pelaku pengambil keputusan di jabatan-jabatan birokrasi, partai politik, dan parlemen. Jika hal tersebut terpenuhi bukan tidak mungkin kebijakan terkait kebutuhan dan kepentingan Tuan Guru akan lebih terpenuhi secara maksimal, karena mereka lebih memahami dan mengalami apa yang dirasakan oleh masyarakat sekitar melalui dakwahnya. 
Lebih lanjut dari hasil wawancara dengan Tim Pemenangan Kampanye Tuan Guru H. Lalu Farhan Rasiyd Makbul calon anggota DPRD Provinis NTB Tahun 2014, mengenai perbandingan suara calon yang bersangkutan dalam hal ini Tuan Guru H. Lalu Farhan Rasiyd Makbul, dengan suara Partai Amanat Nasional (PAN) sebagai perbandingan sebagai berikut: "Secara prolehan suara dari Tuan Guru H. Lalu Farhan Rasiyd Makbul dalam hal mendongkrak elektabilitas partai dan perolehan suara partai, H. Lalu Farhan Rasiyd Makbul rasa sudah maksimal waktu itu. Akan tetapi bagamanapun caranya kita bisa mendongkrak partai dalam hal prolehan suara namun tidak ada sumbangsih suara maksimal dari calon-calon internal dari Partai Amanat Nasional (PAN) Jika dari calon internal Partai Partai Amanat Nasional (PAN) mampu menyumbangkan prolehan suara rata-rata 1000 ribu maka insyaallha Partai Amanat Nasional (PAN) bakalan dapat kursi di DPRD Provinsi NTB tahun 2014 pada dapil 8 selatan antara, Jonggat, Pujut, Praya Barat, Praya Timur, Pringgarata,Praya Barat Daya.

Dari hasil wawancara di atas bahwa Tuan Guru H. Lalu Farhan Rasiyd Makbul sudah cukup maksimal dalam menyumbang suara terhadap Partai Amanat Nasional (PAN), namun kendalanya Partai dan Caleq dari internal Partai Amanat Nasional (PAN) tidak mampu mendongrka perolehan suara, sehingga calon anggota DPRD Provinsi NTB tahun 2014 melalui Partai Amanat Nasional (PAN) yang dari dapil 8 diantarnya, Jonggat, Pujut, Praya Barat, Praya Timur, Pringgarata,Praya Barat Daya tidak ada yang lolos atau mendapatkan kursi.

Prolehan suara partai, sah pada pemilu DPRD Provinsi NTB 9 April 2014, sebanyak 2.533.536 suara, dari total 3,4 juta lebih pemilih sesuai Daftar Pemilih Tetap (DPT). Rincian suara sah sesuai dapil yakni Dapil 1 sebanyak 193.551 suara, Dapil 2 sebanyak 443.787 suara, Dapil 3 sebanyak 382.390 suara, Dapil 4 sebanyak 229.942 suara, Dapil 5 sebanyak 313.532 suara, Dapil 6 sebanyak 467.390 suara, Dapil 7 sebanyak 241.721 suara, dan Dapil 8 sebanyak 261.223 suara. Dari delapan dapil itu, Partai Golkar meraih suara terbanyak yakni sebanyak 373.056 suara, disusul Partai Demokrat sebanyak 305.669 suara, lalu Partai Gerindra sebanyak 265.887 suara, dan PDI Perjuangan sebanyak 216.923 suara, serta Partai Hanura sebanyak 207.550 suara, Partai Keadilan Sejahtera (PKS) sebanyak 206.414 suara, Partai Kebangkitan Bangsa (PKB) sebanyak 199.626 suara, Partai Persatuan Pembangunan (PPP) sebanyak 195.648 suara, PAN sebanyak 195.483 suara. Selanjutnya, Partai Nasionalis Demokrat (NasDem) sebanyak 158.002 suara, dan Partai Bulan Bintang (PBB) sebanyak 139.710 suara, serta Partai Keadilan dan Persatuan Indonesia (PKPI) sebanyak 69.568 suara.(Antaranews.com,12 Mei 2014).

Adapun hasil wawancara dengan salah satu anggota Partai Amanat Nasional (PAN) sebagai responden, mengenai persamaan ideologi dengan calon yang bersangkutan sebagai 
berikut: "Jadi bukan msalah diterima atau tidak diterimanya di masyarakat, ini hanya persoalan bagaimana tim dalam satu Partai Amanat Nasional (PAN) bekerja secara serius sehinga juga tidak terlepas dari partai dengan tokoh yang ada dalam partai. secara ideologi Partai Amanat Nasional (PAN) dan Tuan Guru Farhan sejauh ini sama-sama ingin memperjaungkan aspirasi masyarakat".

Hasil wawancara di atas, menjelaskan bahwa setiap caleq yang menggunakan Partai Amanat Nasional (PAN) menjadi kendaraan politiknya, tentu juga melakukan sosialisai di kalangan masyarakat mengenai caleq internalnya dengan menggunakan strategi yang sudah disusun dalam memenangkan caleq-caleq internal partai baik ditingkat kabupaten/kota sampai tingkat RI dan juga mengenai persamaan ideologi antara Partai Amanat Nasional (PAN) dan Caleq, Partai Amanat Nasional (PAN) tidak sembarangan dalam merekrut kader maupun caleq yang mau menggunakan Partai Amanat Nasional (PAN) sebagai kendaraan politik.

Hal senada juga disampaikan oleh salah satu anggota Partai Amanat Nasional (PAN) sebagai responden yang sudah terlibat sebagai calon legislative tingkat kabupaten Tahun 2014, mengenai persamaan ideologi dengan calon yang bersangkutan sebagai berikut: " kami selain ada aturan AD/ART PAN yang mengatur tentang tata cara rekrutmen anggota legislatif, juga kami melakukan langkah-langkah taktis untuk menjaring para caleq dalam proses politik, dengan kata lain juga kami sebagai caleg tentu melihat dan memilih partai yang kemudian sama ideologi dalam visi perjuangan kami dalam memperjuangkan aspirasi masyarakat, namun kalau partai politik tidak membekali calon anggota legislatifnya dengan serius, tetap aturan tersebut tidak berguna, karena caleg hanya akan menjadi "tempelan" untuk memenuhi kuota tersebut".

Permasalahan yang muncul pada bursa calon legislatif adalah, partai politik belum terlalu serius melakukan kaderisasi secara berjenjang, dan memberikan pendidikan politik yang maksimal bagi anggota atau kader calegnya, sehingga yang muncul, ketika pada waktu pemilu legislatif, caleg hanya untuk memenuhi kuota, atau hanya untuk memenuhi kewajiban undangundang dan aturan yang mengatur pada pemilu legislatif, sehingga yang terjadi caleg yang terpilih pada pemilu legislatif 2014 adalah mereka yang punya akses kekuasaan, yang sudah memiliki basis massa dan memiliki banyak uang, sedangkan yang lainnya lagi-lagi hanya sekedar memenuhi kuota.

Persaingan caleg Tuan Guru akan berat menghadapi sesama caleg Tuan Guru dari partai lain dalam memperebutkan sedikitnya kursi yang tersedia. Perubahan wilayah pemilihan dan penempatan calon jadi di partai adalah hal lain yang harus diperhatikan, karena tidak ada gunanya kalau calon legislatif dari Tuan Guru berada di urutan tengah atau bawah dalam daftar 
calon legislatif, sementara kursi yang diperebutkan di suatu daerah pemilihannya hanya empat atau lima.

Selanjutnya identifikasi kepartaian (Party ID) mempunya dua makna sekaligus. Pertama, adalah keterikatan seseorang pada partai tertentu. Orang mesilnya akan mengidentifikasikan dirinya pendukung Partai Keadilan Sejahtra (PKS) atau Partai Amanat Nasional (PAN) sementara yang lain mendukun Partai Kebangkitan Bangsa (PKB), dan yang lain mendukun partai-partai lainya. Kedua, sikap. Derajat dukungan atau keterikatan secara pisikologis seseorang pada partai yang ia idetifikasi, yang kemudian diukur dengan sekala interval. Disini akan di ketahui apakah ketertarikan dan dukungan seseorang pada salah satu partai itu kuat atau lemah.

Identifikasi partai dilandasi oleh konsep sikap dan sosialisasi.Sikap seseorang sangat mempengaruhi perilaku politiknya. Sikap itu terbentuk melalui proses yang berlangsung lama, bahkan sejak seorang pemilih masih berusia dini. Pada usia dini, seorang calon pemilih telah menerima pengaruh politik dari orang tuanya, baik dalam bentuk komunikasi langsung dangan politik yang diekspresikan orang tuanya.

Hasil wawancara dengan Fitri Hilda, salah satu Masyarakat Desa Ganti, tentang relevansi kedudukan sosial masyarakat dan kedudukan Partai Amanat Nasional (PAN) di Desa Ganti sebagai berikut: "Kalau dikaitkan dengan kondisi sosial masyarakat Desa Ganti yang lebih cendrung religius, sehingga pigur ini tidak mampu membuat elektabilitas Partai Amanat Nasional (PAN) di atas partai-partai seperti PKB, PKS, dan PPP”.

Gambaran hasil wawancara diatas, menunjukan bahwa dikalangan masyarakat desa ganti. PKB, PKS, dan PPP lebih popular dibandingkan dengan Partai Amanat Nasional (PAN), hal ini ditujukan oleh jawaban responden yang menyatakan bahwa kurangnya sosialisai mengenai program yang berkaitan dengan sosial budaya, apalagi program mengenai kegiatan keagamaan. Sehingga dalam tingkat elektabilitas Partai Amanat Nasional (PAN) di Desa Ganti sangat rendah. Tentunya kondisi ini dapat dimanfatakan oleh pihak untuk melakukan mobilisasi bagi kepentingannya memenangkan pemilu.

Lebih jauh lagi mempertegas dari hasil wawancara dengan salah satu Masyarakat Desa Ganti, tentang relefansi kedudukan sosial masyarakat dan kedudukan Partai Amanat Nasional (PAN) di Desa Ganti sebagai berikut: "Kalau Partai Amanat Nasional (PAN) yang saya lihat di Desa Ganti ini, tidak memiliki pengaruh yang cukup besar. Pertama, karena Partai Amanat Nasional (PAN) ini kalau dikaitkan dengan kondisi sosial masyarakat Desa Ganti yang lebih cendrung kepada religius. Partai Amanat Nasional (PAN) walaupun secara ideologi nasionalis dan religius, tetapi yang lebih kelihatan adalah nasionalismenya. 
Berdasarkan hasil wawancara di atas, dapat di ketahui Partai Amanat Nasional (PAN) yang secara ideologinya lebih menujukan nasionalisnya dari pada religius dikalangan masyarakat luas. Akan tetapi dilihat dari asas Partai Amanat Nasional (PAN) ini adalah Ahlak Politik Berlandaskan Agama Yang Membawa Rahmat Bagi Sekalian Alam. Realitas tersebut secara tidak langsung telah "merugikan" caleq internalnya PAN

Hasil wawancara dengan salah satu Masyarakat Desa Ganti, tentang relefansi kedudukan sosial masyarakat dan kedudukan Partai Amanat Nasional (PAN) di Desa Ganti sebagai berikut: "Bagaimanapun caranya Partai Amanat Nasional (PAN) kalau manajeman partainya seperti itu, tidak akan bisa dapat kalau kita bandingkan dengan partai-partai yang lain. Kalau saya lihat partai yang lain, dia sangat mempunyai manajamen yang luar biasa”.

3. Kendala Yang dihadapi partai Amanat Nasional (PAN)

Kendala yang dihadapi Partai Amanat Nasional (PAN) pada pileg 2014 di wilayah Desa Ganti memang begitu kompleks, sehingga dibutuhkan langkah-langkah yang tepat untuk penguatan basis masa, bukan sekedar menjadi syarat formal semata. Sehingga bener-bener terwujud dalam memperjuangkan aspirasi masyarakat melalaui program dan sosialisasinya.

Mobilisasi yang dilakukan partai sangat tergantung dari dua hal utama yakni perubahan atau pergeseran perilaku pemilih dan variasi isu public yang muncul dipermukaan. Partai Demokrat yang bisa meraup prolehan suara dengan begitu fantastis bukanlah disebabkan oleh kemampuan mengelola partai, melainkan lebih banyak disebabkan keuntungan-keuntungan dari luar sebgai pendorong. Citra politik yudihoyono yang bagus memungkinkan terbentuknya afirmasi pemilih yang condong untuk mengikuti pilihan politik berdasarkan hasil pencitraan yang dibentuk, terutama melalui media massa dan saluran-saluran pemerintahannya. Hasil akhir yang menempatkan Partai Demokrat memproleh 20.8\% suara dalam pemilu 2009 memunculkan analisis memudarnya politik aliran dan bangkitnya apa yang disebut sebagai pemilih rasional atau rasionalitas pemilih.

Mobilisasi yang tidak dilakukan melalui saluran kelembagaan menyebabkan pergeseran pada identifikasi kepartaian. Pragmatism menjadi alasan yang efektif bagi partai dan juga pemilihnya dalam membentuk identitas politiknya. Mobilisasi melalui sintimen ideologi menjadi sedemikian kabur saat partai menawarkan cara baru dalam memaknai partisipasi politik konstituen. Hal senanda dirasakan oleh masyarakat Desa Ganti Kabupaten Lombok Tengah, yang dimana Partai Amanat Nasional (PAN) di Desa Ganti secara elektabilitasnya sangat rendah walaupun tokoh dalam partai tersebut memiliki elektabilitas tinggi.Seperti salah satau tokoh dari Desa Ganti Tuan Guru H. Lalu Farhan Rasiyd Makbul yang maju menjadi calon anggota DPRD Provinsi NTB Tahun 2014. 
Hasil wawancara dengan salah satu Masyarakat Desa Ganti, tentang relefansi kedudukan sosial masyarakat dan kedudukan Partai Amanat Nasional (PAN) di Desa Ganti sebagai berikut: "Pada tahun 2014 Partai Amanat Nasional (PAN) sebagai kendaraan politik seorang tokoh yang ada di Desa Ganti, secara pigur Tuan Guru H. Lalu Farhan Rasiyd Makbul elektabilitasnya cukup tinggi yang seharusnya mampu menaikkan elektabilitas Partai Amanat Nasional (PAN)".

Berdasarkan hasil wawanacara di atas menjelaskna bahwa, dari tingkat elektabilitas Tuan Guru H. Lalu Farhan Rasiyd Makbul dikalangan masyarakat Desa Ganti yang cukup tinggi, namun tidak mampu meningkatkan elektabilitas Partai Amanat Nasional (PAN) Hal ini dikarenakan Partai Amanat Nasional (PAN) tidak pernah melakukan kegiatan keagamaan diwilayah Desa Ganti, karena kondisi sosial masyarakat Desa Ganti yang lebih cendrung religius.

Jika ditelah lebih jauh yang disampaikan Tim Pemenangan Kampanye terkait metode atau manajemen dalam proses singkronisasi dan komunikasi oleh Partai Amanat Nasional (PAN) untuk meningkatkan kedekatan dan prolehan suara yang akan dihasilkan oleh caloncalon dari Partai Amanat Nasional (PAN), maka niscaya hasilnya bakalan nihil. Namun sayangnya Partai Amanat Nasional (PAN) tidak mampu memberikan hasil yang memuasakn terhadap calon-calonya. "Secara kepuasan masyarakat dari Tuan Guru H. Lalu Farhan Rasiyd Makbul pada tahun 2014 memang luar biasa tingkat kepuasan masyarakat terhadap individunya. Namun yang menjadi kendala waktu itu adalah kerjasama atau komunikasi antara caleg-caleg internal Partai Amanat Nasionla (PAN) pada dapil selatan yang tidak bisa mendongrak prolehan suara untuk kursi di tingkat DPRD Provinsi NTB tahun 2014.”

Pada tahun 2009 Tuan Guru H. Lalu Farhan Rasiyd Makbul maju sebagai calon anggota DPRD Kabupaten Lombok tengah melalui PKS sebagai kendaraan politiknya dengan hasil yang tidak mengecewakan, Tuan Guru H. Lalu Farhan memperoleh suara yang cukup maksimal. Sehingga dengan modal sebagai incamben, Tuan Guru H. Lalu Farhan berharap memproleh suara maksimal pada pemilihan anggota DPRD Provinsi NTB tahun 2014 melalui Partai Amanat Nasionla (PAN) sebagai kendaraan politiknya. Akan tetapi kenyataannya Partai Amanat Nasionla (PAN) tidak mampu memberikan harapan kepada Tuan Guru H. Lalu Farhan. Sebagaimana hasil wawancara dengan Tuan Guru H. Lalu Farhan Rasiyd Makbul. “dia memilih Partai Amanat Nasional (PAN) sebagai kendaraan politiknya maju menjadi calon angota DPRD Provinsi NTB Tahun 2014. Karena H. Lalu Farhan Rasiyd Makbul melihat potensi untuk menang dan dia membaca berapa kekuatan dari lawan-lawannya di internal”. 
Setiap caleg tentu berahap untuk menang dan setiap caleg tentu memiliki elketabilitas masing-masing, namun perlu juga dari partai yang dijadikan sebagai kendaraan politiknya memiliki leketabilitas di kalangan masyarakat, dengan cara mensosialisaikan program atau kegiatan yang dilakukan partai, bukan hanya sekedar dijadikan kendaraan politik namun tidak bergerak dalam mempromosikan caleg-caleg internal partai, seperti halnya Partai Amanat Nasional (PAN).

Dalam konteks untuk memenangkan caleg, tentu partai dalam hal ini Partai Amanat Nasional (PAN) juga ikut serta dalam memberikan pemehaman politik, melakukan program atau kegiatan yang berkaitan tentang keagamaan dan sebaganiya terhadap masyarakat, sehingga masyarakat tidak memberikan penilaian buruk terhadap partai, dalam hal ini Partai Amanat Nasional (PAN). Sebagaimana Hasil wawancara dengan Masyarakat Desa Ganti, tentang relefansi kedudukan sosial masyarakat dan kedudukan PAN di Desa Ganti sebagai berikut: "Partai Amanat Nasional (PAN) pengaruhnya sangat sedikit karena Partai Amanat Nasional (PAN) ini partai nasionalis-religius tetapi tidak memiliki program dan kegiatan yang jelas tetrutama pada bidang keagamaan, belum juga program-program yang berkaitan dengan budaya, sosial. Partai Amanat Nasional (PAN) ini tidak pernah memiliki satu tawaran program yang jelas terhadap Desa Ganti”.

Dari hasil wawancara di atas Partai Amanat Nasional (PAN) pada wilayah Desa Ganti tidak pernah melakukan kegiatan-kegiatan baik kegiatan secara sosial kemasyarakatan maupun keagamaan dalam menarik perhaitan masyarakt untuk kemudian dipilih pada pemilu, dengan demikian Partai Amanat Nasional (PAN) tidak akan pernah mendapatkan kursi DPRD Provinsi NTB pada dapil 8 (selatan).

Setiap menjelang pemilu, kita seringkali mendengar pernyataan pemilih rasional sebagai karakter pemilih ideal. Pemilu diasumsikan berjalan baik apabila porsi pemilih dengan nalar logis tersebut mendominasi keseluruhan jumlah pemilih. Faktanya, menjelaskan pemilih rasional tidak mudah, karena adanya komleksitas logika dalam mengambil keputusan dalam memilih.

Karakter pemilih rasional yang paling penting yaitu kemampuan kalkulasi, pemilih bisa membandingkan opsi-opsi kebijakan yang ditawarkan kandidat. Dalam hal ini calon anggota DPRD Provinsi NTB Tuan Guru H. Lalu Farhan Rasiyd Makbul. Berikutnya, tawaran kebijakan yang paling mendekati kebutuhan dan permintaan pemilih memberi peluang bagi caleg untuk dipilih. Maka caleg yang dinilai berpeluang lebih tinggi akan dipilih berdasarkan kalkulasi dan kesesuaian. 
Persyaratan penting munculnya pemilih rasional adalah kecukupan informasi mengenai pemiliu legislatif, untuk melakukan kalkulasi, menemukan kesesuaian, dan memilih secara strategis, pemilih harus mendapat suplai informasi caleg maupaun partai yang cukup, kampanye merupakan salah satu metode yang paling sesuai untuk memenuhi kecukupan informasi.

Pada proses pemilihan calon anggota DPRD Provinsi NTB Tahun 2014, telah melakakan penyampaian informasi mengenai program-program yang jelas dikalang masyarakat, khusunya masyarakat desa ganti. Tentu juga telah melakukan gerakan atau mensosialisasikan program partai dan sosialisai mengenai caleg dari Partai Amanat Nasional (PAN) dikalangan masyarakat, seperti caleg Tuan Guru H. Lalu Farhan Rasiyd Makbul. Sebagaimana Hasil wawancara dengan dengan anggota Partai Amanat Nasional (PAN), sebagai berikut: "Kami dari Partai Amanat Nasional (PAN) cukup massif dalam melakukan penyampaian dan mensosialisaikan informasi di kalangan masyarakat, mengenai program Partai dan setiap caleg yang menggunakan Partai Amanat Nasional (PAN) sebagai kendaraan politiknya, begitu pula kami lakukan di wilayah Desa Ganti”.

Melihat hasil wawancara di atas, dari anggota Partai Amanat Nasional (PAN) menyatakan sudah melakukan gerakan secara massif dalam melakakan penyampaian dan mensosialisaikan informasi di kalangan masyarakat, mengenai program Partai dan setiap caleg yang menggunakan Partai Amanat Nasional (PAN) sebagai kendaraan politiknya di wilayah Desa Ganti, akan tetapi walaupun sudah melakukan gerakan secara massif, namun tidak membuat para caleg dari Partai Amanat Nasional (PAN) terutama Tuan Guru H. Lalu Farhan Rasiyd Makbul lolos sebagai anggota DPRD Provinsi NTB pada pemilu 2014.

Lebih lanjut lagi mengenai keterbukaan informasi dan mensosialisaikan program dari Partai Amanat Nasional (PAN) beserta mengkampanyekan caleg-caleg dari internal Partai Amanat Nasional (PAN). Dibawah ini hasil wawancara dengan masyarakat Desa Ganti terkait perbandingan Partai dan Caleg. "kalau saya melihat dari partainya hanya 30\% dan yang 70\% itu murni dari individu calon dalam memproleh suara, karena pada masyarakat Desa Ganti cendrung melihat ketokohan para caleg dari pada partai, seperti partai amanat ansioanl (PAN), begitu pula dengan persoalan ideolgi, saya rasa tidak ada persoalan, asalakan jangan berideologi nasrani". 


\section{PENUTUP}

Pemenangan pemilu tidak terlepas dari proses sosialisasi politik partai politik. Proses sosialisasi politik merupakan proses penanaman nilai-nilai kepada masyarakat. Hal ini merupakan proses penting guna memberikan informasi, pandangan dan pengetahuan tentang kehidupan politik, Proses sosialisasi politik pemilu legislatif 2014 Partai Amanat Nasional (PAN) dapat dikatakan tidak terlaksana dengan maksimal. hal ini dapat dibuktikan bahwa Partai Amanat Nasional (PAN) tidak dapat meraih kursi pada pemilihan anggota DPRD Provinsi NTB tahun 2014, di wilayah pemiihan Kabupaten Lombok Tengah dapil 8 selatan, diantaranya, Jonggat, Pujut, Praya Barat, Praya Timur, Pringgarata, Praya Barat Daya.

Dengan demikian penelitian tentang Kegagalan Tuan Guru H. Lalu Farhan Rasiyd Makbul dalam persfektif identifikasi partai (Party ID) dalam memenangkan pemilihan legislatif tahun 2014 dapat diberi kesimpulan sebagai berikut: Pertama; Kegagalan Tuan Guru H. Lalu Farhan Rasiyd Makbul dalam persfektif identifikasi partai (Party ID) dalam memenangkan pemilihan legislatif tahun 2014 di Kabupaten Lombok Tengah, pada ketertarikan ideologi partai memperlihatkan Tuan Guru H. Lalu Farhan Rasiyd Makbul memilih Partai Amanat Nasional (PAN) sebagai kendaraan politiknya yang dimana Partai Amanat Nasional (PAN) secara ideologi Pancasila Nasionalis-Religius. Namun realitanya Partai Amanat Nasional (PAN) tidak mampu mendapatkan kuris pada pemilihan anggota DPRD Provinsi NTB tahun 2014. Hal ini diakibatkan kurangnya Sosialisasi politik Partai Amanat Nasional (PAN) pada pemilu Legislatif 2014 lebih banyak dilaksanakan oleh Caleg-caleg internal partai, Kedua; Dalam tingkat kepuasan masyarakat terhadap anggota DPR dari partai Partai Amanat Nasional (PAN) tidak merasa puas walaupun secara elektabilitas tokoh yang ada di Partai Amanat Nasional (PAN), tapi tidak mampu memberikan kepuasan terhadap masyarakat. Hal ini diakibatkan Partai Amanat Nasional (PAN) tidak pernah mensosialisasikan program-programnya, Ketiga; Selanjutnya, Setiap menjelang pemilu, kita seringkali mendengar pernyataan pemilih rasional sebagai karakter pemilih ideal. pemilih rasional pada pemilihan anggota DPR dari Partai Amanat Nasional (PAN) meperlihatkan klasipikasi pemilih dalam konteks kelas sosial, yang dimana kebanyakan pemilih Partai Amanat Nasional (PAN) dari kalangan wiraswasti dari pada golongan pengajar, petani, dan buruh. Hal ini diakibatkan, Partai Amanat Nasional (PAN) kurangnya sosialisasi atau menyampaikan informasi mengenai kandidat ataupun program yang akan dijalankanyna selama menjadi anggota DPRD dari Partai Amanat Nasional (PAN) terpilih.

Berdasarkan kesimpulan yang diperoleh dari penelitian tentang Kegagalan Tuan Guru H. Lalu Farhan Rasiyd Makbul dalam persfektif identifikasi partai (Party ID) dalam 
memenangkan pemilihan legislatif tahun 2014 di Kabupaten Lombok Tengah, dapat dikatakan bahwa secara ideologi Partai Amanat Nasional (PAN) dikalangan masyarakat tidak ada masalah, artinya masyarakat dalam hal ideologi partai itu bukan jadi persoalan, namun yang paling penting bagi masyarakat bahwa Partai Amanat Nasional (PAN) harus mampu memberikan solusi atau program-programnya di tengah masyarakat bawah, bukan hanya melakukan pendekatan terhadap masyarakat elit.

Menurut penulis setelah mengadakan penelitian di Desa Ganti dalam mengidetifikasi parati (Party ID) Amanat Nasional. penulis dapat menilai bahwa Partai Amanat Nasioanal (PAN) tidak sukses dalam melaksanakan proses sosialisasi politik terhadap masyarakat pemilih di wilayah Desa Ganti Kabupaten Lombok Tengah pada pemilihan legislatif tahun 2014. Seperti mana yang kita ketahui bahwa tujuan dari identifikasi partai dapat kita ketahui sejauhmana proses sosilisasi politik yang dilakukan partai. Dalam hal ini Partai Amanat Nasional (PAN) hendaknya dalam sosialisasi politik Partai Amanat Nasional (PAN) tidak hanya terfokus pada basis masyarakat elit saja, tetapi harus mencakup basis pemilih yang lebih luas diluar basis pemilih. Mengingat bangsa Indonesia adalah bangsa yang pluralitas disegala aspek kehidupan masyarakat.

Untuk memaksimalkan prolehan suara Partai Amanat Nasional (PAN) di wilayah pemilih Desa Ganti Kecamatan Praya Timur Kabupaten Lobok Tengah. hendaknya memperhatikan aspek-aspek pluralitas dalam partai politik artinya berdasarkan hasil penelitian ditemukan adanya potensi untuk mendapatkan kursi pada pemilihan legislatif, dengan lebih memperbanyak penekanan anggota DPRD dari Partai Amanat Nasional (PAN) dalam menampung aspirasi masyarakat, tentu juga dalam hal program yang dilakukannya harus jelas, dan tidak telepas untuk pendekatan terhadap masyarakat elit saja, namu harus melakukan pendekatan terhadap masyarakat tanpa melihat kelas sosial. sehingga pemilih pada pemilih diluar basis Partai Amanat Nasional (PAN) untuk kedepannya kiranya jauh lebih baik dibangding sebelumnya agar Partai Amanat Nasional (PAN) dapat memperoleh jumlah suara atau kusri yang maksimal di parlemen.

\section{DAFTAR PUSTAKA}

Budiardjo Miriam, 2010. Dasar-Dasar Ilmu Politik. PT.Ikrar MandiriAbadi,Jakarta:

Basrowi Sukidin.2012. Sosiologi Politik. Bogor Ghalia Indonesia:

Darmansyah, 2003.Seri Pendidikan Politik Lokal; DPRD dan Partai Politik.P3OD UMM. Mataram:

Dahlan Fahrurroiz, 2006. Sejarah perjuangan dan Pergerakan Dakwah Islamiyah Tuan Guru Haji Muhammad Mutawalli di Pulau Lombok (Pendekatan Kultur dan Sufistik Dalam Mengislamisasi Masyarakat Wetu Telu). Sentra Media. Pisangan Ciputat: 
Hendarsah Amir, 2009.Buku Pintar Politik; Sejarah, Pemerintahan, dan Ketatanegaraan. Percetakan Galangpress. Yogjakarta:

Hamdi Saipul, 2014. Nahdlatul Wathan Di Era Reformasi (Agama, Konflik dan Peta Rekonsiliasi).Perpustakaan Nasional RI Dalam Terbitan (KDT):

I.B Wirawan,2012.Teori-Teori Dalam Tiga Paradigma. Kencana Prenada media, Jakarta:

Naamy Nazar, 2016. Politik Tuan Guru Antara Idealitas Moral dan Pragmatism.Sanabil Puri Bunga Amanah. Mataram:

Ridwan, (2008 : 69). Dalam Moelong, Metodelogi Penelitian Kualitatif, 2005)

Satori Djam'an dan Aan Komariah, Dalam Lexy J. Moelong, Metodelogi Penelitian, 2006.

Sugiyono, 2013. Dalam Ahmad Tanzeh, Metodelogi Penelitian Praktis. Yogyakarta : Teras, 2011

Anwar, Muh. Samsul, 2012.Dinamika Politik Islam Sasak ; Tuan Guru dan Politik Pasca Orde Baru. Skripsi UIN syarif hidayatullah Jakarta:

Abdad, M. Zaidi, 2015 Dinamika pergeseran tuan guru di Lombok (studi analisis melalui pendekatan teori deferensiasi struktural Talcott parson). UIN Mataram:

AkbarSyahrizal, 2013.Kajian sosiologi Sastra Dan Nilai. Jurnal Pendidikan Bahasa dan Sastra. Vol 1, No 1:

Khaidir Yusran , 2012. Peranan Tuan Guru Kyai Haji Muahammad Zainuddin Abdul Madjid Dalam Pengembangan Pendidikan Islam di Nahadlatul Wathan. (Skripsi) Universitas Islam Negeri Syarif Hidayatullah Jakarta:

Putrawan, DediAgus, 2015 Dekarismatisasi Di Lombok NTB (Studi tentang pudarnya pesoan Tuan Guru dalam politik pemilihan umum 2014). Pascasarjana UIN Suanan Kalijaga Yogjakarta:

Sabirin, 2008.Konfigurasi Pemikiran Tuan Guru Terhadap Wahabisme.Universitas Indonesia.Program Pascasarjana:

http://file.upi.edu/Direktori/FIP/JUR._PSIKOLOGI_PEND_DAN_BIMBINGAN/1960050119 86031-NANDANG_RUSMANA/Konsep_Dasar_Dinamika_Kelompok.pdf http://www.abimuda.com/2015/11/pengertian-dinamika-sosial-menurut-para.html http://karinakandhik.blogspot.co.id/2012/04/role-theory-teoriperan-role-theory.html http://wahyusofyanto55.blogspot.co.id/2015/08/status-dan-peran-sosial.html 